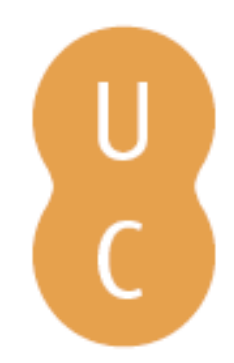

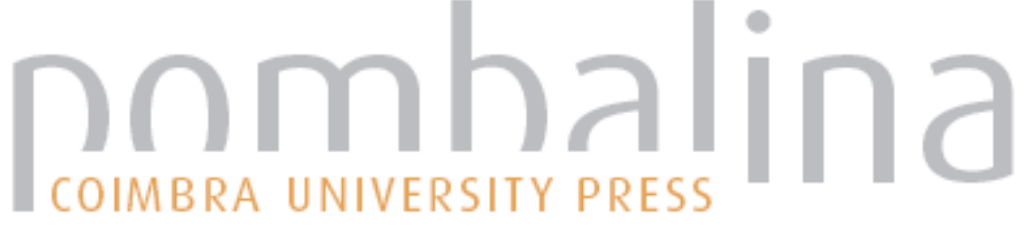

\section{Análise pragmática da narrativa: teoria da narrativa como teoria da ação comunicativa}

Autor(es): $\quad$ Motta, Luiz G.

Publicado por: Imprensa da Universidade de Coimbra

URL

persistente: URI:http://hdl.handle.net/10316.2/41342

DOI: DOl:https://doi.org/10.14195/978-989-26-1324-6_2

Accessed : $\quad$ 26-Apr-2023 01:59:10

A navegação consulta e descarregamento dos títulos inseridos nas Bibliotecas Digitais UC Digitalis, UC Pombalina e UC Impactum, pressupõem a aceitação plena e sem reservas dos Termos e Condições de Uso destas Bibliotecas Digitais, disponíveis em https://digitalis.uc.pt/pt-pt/termos.

Conforme exposto nos referidos Termos e Condições de Uso, o descarregamento de títulos de acesso restrito requer uma licença válida de autorização devendo o utilizador aceder ao(s) documento(s) a partir de um endereço de IP da instituição detentora da supramencionada licença.

Ao utilizador é apenas permitido o descarregamento para uso pessoal, pelo que o emprego do(s) título(s) descarregado(s) para outro fim, designadamente comercial, carece de autorização do respetivo autor ou editor da obra.

Na medida em que todas as obras da UC Digitalis se encontram protegidas pelo Código do Direito de Autor e Direitos Conexos e demais legislação aplicável, toda a cópia, parcial ou total, deste documento, nos casos em que é legalmente admitida, deverá conter ou fazer-se acompanhar por este aviso.

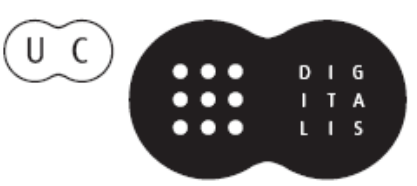





\section{ANÁlISE PRAGMÁTICA DA NARRATIVA: TEORIA DA NARRATIVA COMO TEORIA DA AÇÃO COMUNICATIVA}

No cotidiano de nossas vidas entramos e saímos constantemente no espaço das mídias impressas, eletrônicas e digitais, e nelas nos abastecemos. A mídia nos oferece pontos de referência, pontos de parada, pontos para olhar, se engajar e desengajar (Silverstone, 1999). A configuração de uma narrativa pública hoje é uma prática viva, transmidiática e intertextual (Scolari, 2009). Cada um de nós constrói seus próprios significados a partir de fragmentos de informações extraídos do fluxo midiático, através dos quais procuramos compreender nossas vidas. Essa cultura midiática e digital substituiu a sociabilidade tradicional, transformou-se em uma nova textura geral da experiência (Berlin, 1997) ou uma mundanidade mediada (Thompson, 1998). Nesse caleidoscópico fluxo e refluxo de socialização travam-se as batalhas discursivas pela posse dos significados, representações e senso comum. Na cultura da convergência (Jenkins, 2006), as narrativas públicas se configuram através da intersecção de uma multiplicidade de fontes e plataformas: cada fragmento acrescentado distende a narrativa para trás, para adiante ou para os lados, reatualiza a história deixando os relatos em um permanente estado de suspensão. 
Essa realidade nova sugere procedimentos de análise da narrativa mais dinâmicos que aqueles fornecidos pela linguística ou a teoria literária. O presente ensaio propõe que a narrativa seja compreendida como uma ação, cujo protagonismo, voz e perspetiva dos sujeitos narrador e destinatário na coconstrução do sentido sejam incorporados à análise. Até recentemente, a análise da narrativa concentrava-se no enunciado, no relato enquanto um produto acabado possuidor per se de um sentido autônomo. O foco se centrava na descoberta de estruturas recorrentes da narrativa que revelassem sua organicidade interna como um sistema fechado sobre si mesmo, com moto próprio: uma totalidade integral que agregava descrições de ações em um transcorrer sucessivo rumo a um desfecho. Categorias como encadeamento, sequência, composição, duração, ritmo, função e outras desempenhavam um papel fundamental nas análises. O importante era desvelar as constantes internas que compunham um modelo universal da intriga. Esse modelo de análise imanentista, inspirado no estruturalismo - episteme hegemônica na segunda metade do século passado - revelou-se por si mesmo insuficiente para compreender a dinâmica das narrativas na sociedade moderna. O esgotamento da narratologia estruturalista suscitou a necessidade de instrumentos capazes de capturar a comunicação narrativa. Esses instrumentos já estavam se consolidando bem antes do advento das mídias digitais. A dinâmica das novas modalidades apenas tornou o modelo imanentista ainda mais obsoleto.

É no bojo das alternativas epistemológicas trazidas pelo linguistic turn que uma narratologia crítica brotou. As inspirações vieram das teorias dos filósofos da linguagem H. P. Grice (1957; 1969), J. H. Austin (1962), J. R. Searle (1998; 2002; 2002a), e outros. E se abasteceram nas sistematizações da pragmática, no final do século passado (Reyes, 1994; van Dijk, 1987 e 2000; Vidal, 2002). Aqui, não posso recuperar as variadas proposições do linguistic turn nem as 
contribuições da pragmática. ${ }^{20}$ No presente ensaio, não ofereço uma sistematização teórico-metodológica acabada de um novo caminho epistemológico. Essa tarefa exigirá maior maturação intelectual. Há, aqui, apenas um esboço conceitual e metodológico preliminar que sugere interpretar as narrativas como atos de fala dinâmicos e circunstanciais, não como produtos fechados sobre si mesmos. Proponhome esboçar formulações preliminares de uma narratologia crítica, ainda nascente, que parece representar uma ruptura radical com os modelos anteriores de análise. Não tenho a pretensão de criar uma nova narratologia, obviamente. Até porque a maioria das ideias aqui ensaiadas são importadas de teorias desenvolvidas em outras áreas do conhecimento. Apenas tento produzir a síntese de um projeto de interpretação de narrativas que parece promissor. Pretendo somente sugerir um caminho alternativo a fim de que a narratologia alcance um status mais antropológico, para além dos restritos limites da linguística e da teoria literária.

No projeto de uma narratologia crítica aqui esboçado, sigo em parte a teoria pragmática dos atos de fala, segundo a qual os atos enunciativos "são operações em contexto, como funções de contexto em contexto" (Levinson, 2007:352, grifo meu), entendidos estes como um conjunto de proposições que descrevem crenças, conhecimentos, compromissos e ideologias dos participantes. Quando uma narrativa é enunciada, acontecem mais coisas que apenas a expressão do seu significado, pois o conjunto de fundo também é alterado. A contribuição que uma enunciação fornece à mudança do contexto é a força ilocucionária, ou potência do ato de fala. A tese de Levinson, com a qual concordo, é que essa força é irredutível à questões de conteúdo, verdade ou falsidade do enunciado, pois constitui um aspecto do significado que não pode ser capturado pela semântica veridicional.

\footnotetext{
${ }^{20}$ Aos interessados, remeto à Parte 1 do meu livro Notícias do fantástico (Motta, 2006). E particularmente à coletânea de ensaios reunidos sob o título La búsqueda del significado, de L. M. Valdés Villanueva (2000).
} 
"O lugar próprio da força ilocucionária é o domínio da ação, e as técnicas adequadas para a análise devem ser encontradas na teoria da ação, não na teoria do significado", uma maneira inteiramente pragmática de lidar com a força ilocucionária (Levinson, 2007:312, grifo dele).

Sigo também a hermenêutica crítica de Paul Ricoeur (1983: 46:7), para quem o discurso é um evento realizado no presente, que remete ao seu locutor mediante um conjunto complexo de indicadores. O caráter do evento vincula-se, assim, à pessoa que fala. Mais ainda, o evento consiste no fato de alguém falar, tomar a palavra para expressar-se a respeito de algo: refere-se a um mundo que pretende descrever ou representar. Neste sentido, o ato de fala é a vinda à linguagem de um mundo mediante o discurso, e não somente um mundo, mas também o outro, outra pessoa, um interlocutor ao qual o locutor se dirige. É da tensão entre estes dois polos que surge a produção do discurso como obra (o sentido). O que a hermenêutica deve compreender, diz Ricoeur, "não é o evento, na medida em que é fugidio, mas sua significação que permanece". ${ }^{21}$ A obra traz uma proposição de mundo "que não se encontra atrás do texto como uma espécie de intenção oculta, mas diante dele como aquilo que a obra desvenda, descobre, revela" (1983:58).

Em trabalho anterior, sugeri que a narratologia deveria deslocar-se da teoria literária para tornar-se um procedimento multidisciplinar de caráter cultural e cognitivo, envolvendo a interpretação de mitos, ideologias e os valores canônicos e políticos da sociedade (Motta, 2013). O presente ensaio pretende avançar nesse rumo, até porque nunca antes a rotina de vida das sociedades foi tão permeada por uma complexa enxurrada de narrativas como hoje. Cognitivamente, elas configuram o sentido ordinário da vida. Quotidianamente, somos

\footnotetext{
${ }^{21}$ Ricoeur (1983:56) ressalta: o que deve ser interpretado no texto é uma proposição de mundo, "um mundo tal como posso habitá-lo para nele projetar um de meus possíveis mais próprios". O mundo do texto, próprio e único deste texto.
} 
inundados por biografias, mini-contos, breves romances, reportagens, filmes, documentários, telenovelas, canções, videoclipes, videogames, histórias em quadrinhos, desenhos animados, comerciais de TV, anedotas, diários de vida, breves relatos do facebook, whatsapp, Instagram e outras redes sociais digitais. Através das novas tecnologias, o público tomou para si um protagonismo maior do contar. Nunca antes nossas estórias foram tão compartidas, tornando mais densa e complexa a rede coletiva de narrativas públicas. Nunca antes fomos tão narradores, e simultaneamente destinatários, de nossas próprias aventuras. A vida contemporânea se desenvolve sob um mar de relatos híbridos e fragmentados que se emendam uns aos outros, entretecendo uma teia virtual de narrativas na qual estamos todos enredados. Provenientes de diferentes plataformas, descontínuos e dispersos, fáticos ou fictícios, locais ou universais, comerciais ou públicos, informativos ou puro entretenimento, poucos desses relatos alcançam constituir-se peças literárias. São erráticos, efêmeros e caleidoscópicos. Mal ou bem, entretanto, os relatos públicos configuram as narrativas multimidiáticas ou transmidiáticas da modernidade e constituem o mar de híbridas histórias que confirmam a hegemônica cultura da convergência.

\section{Teoria da narrativa como uma teoria da ação}

A tese de Paul Ricoeur no tomo I de seu reconhecido ensaio Tempo e Narrativa (1994) é que a operação de configuração da tessitura de uma intriga extrai sua inteligibilidade de sua faculdade de mediação entre a prefiguração (processo de produção) e a refiguração (processo de recepção). Ou seja, a obra eleva-se do fundo opaco do viver e agir para ser dada por um autor à um leitor que a recebe e, assim, muda seu agir. A hermenêutica ricoeuriana, dessa forma, preocupa-se em reconstruir o arco inteiro das operações da experiência: a obra media 
entre autores e leitores. O desafio, segundo ele, é a reconstituição do processo concreto pelo qual a configuração (mimese II) faz a mediação entre a prefiguração (mimese I) e sua refiguração (mimese III). Assim, o autor subordina a questão do encadeamento narrativo à determinação da função mediadora da intriga: ela media entre o momento da experiência prática que a precede e o estágio da experiência receptora que a sucede. ${ }^{22}$

Se é verdade que a intriga é uma imitação das ações humanas, quem a compõe parte de uma pré-compreensão do mundo, suas estruturas inteligíveis, simbólicas e temporais; e sua competência para articular a representação das ações em uma trama. Mais importante ainda, diz Ricoeur, é observar que quem compõe age com certas motivações a fim de produzir certos efeitos. Torna-se então importante, observa ele, identificar o agente e seus motivos. Ademais, prossegue, agir é sempre agir 'com' outros: "a interação pode assumir a forma de cooperação, de competição ou luta" (Ricoeur, 1994:89). A compreensão narrativa deve, pois, ser estabelecida entre a teoria narrativa e a teoria da ação: "Compreender uma história é compreender ao mesmo tempo a linguagem do 'fazer' e a tradição cultural da qual procede a tipologia das intrigas" (Ricoeur, 1994:91).

Pelo lado da recepção, observa Ricoeur, "a narrativa tem seu sentido pleno quando é restituída ao tempo do agir e do padecer", no momento em que é lida. A recepção, segundo ele, "marca a intersecção entre o mundo do texto e o do leitor". O mesmo 'pano de fundo'

\footnotetext{
${ }^{22}$ Ricoeur retoma este assunto no capítulo 3, tomo II, de Tempo e Narrativa (1995) onde reconhece a necessidade do deslocamento de atenção do enunciado para o ato de enunciação, passando para primeiro plano os jogos entre a inclusão e exclusão de conteúdos, a ideologia em última instância. Ao final deste capítulo, o autor explica que as noções de voz e perspetiva narrativa precisam ser incorporadas à análise da composição narrativa. Isso se faz, diz ele, vinculando-as às categorias de narrador e personagem. Ricoeur admite que a questão do ponto de vista diz respeito à composição, mas o problema da voz narrativa é uma questão de comunicação na medida em que ela se dirige a um leitor (Ricoeur, 1995:163).
} 
da cultura, de histórias vividas e (ainda) não contadas, imbricadas umas às outras, sobre as quais as novas histórias emergem, opera aqui: "Narrar, seguir, compreender histórias é só a 'continuidade' dessas histórias não ditas" (Ricoeur, 1994:116). No ato de ler, diz ele, o leitor reconfigura e conclui a obra: "É o leitor, quase abandonado pela obra, que carrega sozinho o peso da tessitura da intriga" (Ricoeur, 1994:118). O ato de leitura, conclui, é "o último vetor da configuração do mundo da ação sob o signo da intriga" (Ricoeur, 1994:118). Não preciso prosseguir com a rica argumentação de Paul Ricoeur a respeito da narrativa como uma teoria da ação comunicativa. Ficou evidente que configurar e refigurar uma intriga são ações protagonizadas por sujeitos vivos e ativos, são performances linguísticas movidas por motivações e intenções recíprocas. As breves citações acima são suficientes para indicar uma total reviravolta proposta por ele (e outros autores) na teoria e análise da narrativa, pois a teoria da narrativa torna-se uma teoria da ação comunicativa. É nessa direção que procederei rumo a uma análise pragmática, a ela anexando o adjetivo crítica pelo seu potencial de contextualizar a interpretação narrativa.

É importante trazer a palavra avaliadora de Paul Ricoeur a respeito da narrativa como ato de fala por causa da respeitabilidade dele no campo da narratologia. Entretanto, Ricoeur não é uma referência fundamental na teoria dos atos de fala, que provém da filosofia da linguagem. Até pouco tempo atrás, os filósofos e linguistas estavam preocupados com a competência linguística de cada frase ou texto, e sua correspondência com a verdade. A virada aconteceu em meados do século passado, quando alguns filósofos explicaram que falar não é somente emitir frases para comunicar informações: a fala realiza coisas para além dos conteúdos proposicionais, e o mais importante talvez não seja a sentença proferida, e sim o que ela obtém como seu efeito independente de sua condição de verdade. Toda vez que falamos, realizamos 
um ato de fala: faço uma pergunta, dou uma ordem, explico ou predigo algo, etc. ${ }^{23}$

Ou seja, para além dos conteúdos, há uma força implícita na fala, que o filósofo J. Austin (1962) chamou de ilocução. Os potenciais efeitos desses atos junto aos receptores, ele chamou de atos perlocutivos. Os atos ilocutivos detém quase sempre uma intenção realizativa: pretendem algo. A mente do sujeito falante impõe intencionalidade aos sons, imagens ou textos, conferindo a eles um significado relacionado à realidade. ${ }^{24}$ Para J. Searle $(1998,127)$, seguidor de Austin, o significado é uma forma de intencionalidade derivada: a intencionalidade intrínseca do pensamento do falante se transfere às palavras e frases pronunciadas. Mas, a intenção de comunicar não coincide sempre com a intenção de significar. Comunicar é obter que o outro reconheça a minha intenção de produzir certo efeito, obter que o outro capte o meu significado.

Se transplantamos essas reflexões da filosofia da linguagem para a narratologia, torna-se relevante redefinir a narração (ou enunciação narrativa) como um ato de fala comunicativo porque os relatos sempre implicam em efeitos não necessariamente referenciados no texto: as narrativas são por natureza irônicas, trágicas, cômicas,

\footnotetext{
${ }^{23}$ Segundo J. Searle (1979), todas as enunciações caem dentro de cinco categorias básicas: elas podem ser assertivas (descrevem como as coisas são), diretivas (levam as pessoas a realizar coisas), compromissivas (comprometem as pessoas), expressivas (expressam sentimentos) ou declarativas (provocam mudanças no mundo) (Searle, 1979). Essas mesmas cinco categorias são resumidas em outras obras do autor. Ver Searle, 2001:133-135. É discutível se todas proposições cabem dentro de apenas cinco categorias.

${ }^{24}$ Autores de variadas áreas sociais desenvolveram posteriormente a teoria da ação. No que concerne à comunicação, J. B. Thompson (1998), por exemplo, critica J. Austin e seus seguidores porque eles não conduziram suas reflexões para uma contextualização social dos atos de fala. Por isso, as considerações deles tenderiam a ser um tanto formais e abstratas, divorciadas das circunstâncias de poder nas quais os indivíduos e instituições utilizam a linguagem no dia a dia. Para Thompson, nós podemos retomar as observações de Austin somente se desenvolvermos uma teoria social substantiva da ação e dos tipos de poder em que ela se baseia. Concordo em parte com essas observações, e sigo em uma direção semelhante na proposta apresentada neste ensaio.
} 
etc. Cada uma delas quer produzir determinado efeito de sentido, muitas vezes apenas subentendido. Assim, precisamos partir de uma definição de comunicação que descreva adequadamente o processo de narração como um ato de fala com os seus possíveis efeitos de sentido. Encontro uma definição adequada em Levinson (2007:19), que diz:

\begin{abstract}
A comunicação consiste no fato de o emissor intentar fazer com que o receptor pense ou faça alguma coisa, simplesmente fazendo o receptor reconhecer que o emissor está tentando causar tal pensamento ou a ação. Portanto, a comunicação é um tipo complexo de intenção, que é realizada ou satisfeita simplesmente por ser reconhecida. No processo de comunicação, a intenção comunicativa do emissor torna-se conhecimento mútuo para o emissor (F) e o receptor $(\mathrm{O})$, isto é, $\mathrm{F}$ sabe que $\mathrm{O}$ sabe que $\mathrm{F}$ sabe que $\mathrm{O}$ sabe (e assim $a d$ infinitum) que $\mathrm{F}$ tem esta intenção específica.
\end{abstract}

Os atos de comunicação (incluindo a narração) são regidos por acordos implícitos entre os interlocutores que tornam possível entender o significado literal, mas também inferir outras significações a partir da força ilocutiva do enunciado. Esse acordo virtual revela a intenção de quem fala e sugere uma interpretação cooperativa de quem lê, vê ou escuta uma história. Ajustamos automaticamente esses acordos em nossas relações cotidianas com os nossos diversos interlocutores, readaptando continuamente as nossas expectativas e as deles, tornando cada fala um ato de comunicação singular e circunstancial. Assim, o que se diz não é necessariamente o que se comunica em cada situação: há diversas implicaturas e pressuposições insinuadas, gestos, dêiticos, etc. Os dêiticos (sutis referências de espaço, tempo, hierarquia social, etc.) são particularmente relevantes porque revelam a importância do contexto comunicativo 
para a compreensão dos significados. Conforme observa Levinson (2007), os dêiticos gramaticalizam traços do contexto na enunciação e revelam como a interpretação das narrações depende da consideração do ambiente da enunciação (voltarei à questão dos dêiticos adiante).

Por sua natureza criativa, a enunciação narrativa é rica em implicaturas e pressuposições que direcionam a fala rumo a inúmeros efeitos de sentido (espera, suspense, susto, sofrimento, riso, assombro, medo, etc.). Elas estão presentes na própria estruturação dramática do texto, na criação do suspense, no amplo uso de figuras de linguagem (metáforas, ironias, hipérboles), na intertextualidade, na ênfase e hierarquia lexicais que põem a comunicação narrativa em funcionamento. O uso intencional desses recursos de linguagem constitui a dimensão pragmática da comunicação narrativa: significados virtuais que decorrem das intencionalidades do sujeito narrador e das interpretações do sujeito receptor (os atos ilocutivo e perlocutivo). As intenções do autor e sua realização (ou não) no ato de recepção são os dois extremos de uma atividade de comunicação em que o texto funciona como o nexo entre os interlocutores. Ou seja, a comunicação narrativa visa provocar mudanças no estado de ânimo das pessoas, podendo eles serem positivos quando favorecem a auto-afirmação (amor, compreensão, compaixão), ou negativos quando a desfavorecem (medo, ira, inveja) (Motta, 2006). Embora brevemente, creio ter enumerado até aqui argumentos suficientes para justificar que o relato não é mera representação da vida, mas um ato comunicativo impregnado de força ilocutiva: realiza sempre uma interlocução criativa. Neste rumo pragmático, a teoria da narrativa distancia-se da teoria literária para tornar-se uma teoria da ação comunicativa. Seu uso deixa de atender apenas à crítica literária ou estética para tornar-se uma metodologia crítica dos atos narrativos. 


\section{A dimensão crítica da pragmática}

A disciplina da pragmática é relativamente recente entre as teorias da linguagem. Sobre a pragmática narrativa, não há literatura específica. A própria teoria dos atos de fala só há pouco saiu do campo da filosofia e começou a se constituir em um projeto metodológico mais consistente. Não há sequer uma definição precisa nem delimitação do alcance da pragmática (Levinson, 2007; Dascal, 2006). ${ }^{25}$ Ela surgiu como uma disciplina um tanto marginal, que se ocuparia das coisas que a semântica e outras disciplinas linguísticas desprezavam (as pressuposições, subentendidos, ironias, etc.), a chamada "cesta de lixo" de Gottlob Frege, ou resíduos de outras teorias (Reyes, 1994; Dascal, 2006). O interesse atual pela pragmática decorreu da percepção geral de que a língua é utilizada para comunicar, e a comunicação é mais que um conteúdo proposicional. A partir daí, linguistas, filósofos e outros se deram conta da necessidade de considerar o contexto dinâmico do uso da linguagem, a performance e motivações (intencionalidades) dos sujeitos interlocutores. ${ }^{26}$

Há consenso que a pragmática refere-se ao estudo do uso que os sujeitos interlocutores fazem da linguagem em um determinado contexto comunicativo (Reyes, 1994). Das condições que determinam o emprego de um enunciado concreto por parte de um falante concreto em uma situação de comunicação concreta, tanto quanto a

\footnotetext{
${ }^{25}$ Vidal (2002) define pragmática como uma disciplina que toma em consideração os fatores extralinguísticos que determinam o uso da linguagem. Reyes (1994) a nomeia como uma disciplina linguística que estuda como os seres falantes interpretamos enunciados em contexto. Dascal (2006) diz que a pragmática é o estudo do uso dos meios linguísticos (ou outros) por meio dos quais um falante transmite as suas intenções comunicativas, e um ouvinte as reconhece. Levinson (2007) define a pragmática como o estudo das relações entre língua e contexto que são gramaticalizadas ou codificadas na estrutura da língua: o estudo apenas dos aspectos da relação entre a língua e o contexto que são relevantes para a elaboração das gramáticas. Van Dijk (2000) contribui com uma teoria cognitiva da pragmática, cuja razão fundamental é estabelecer relações entre os enunciados (a linguística) e a interação (as ciências sociais).
}

${ }^{26}$ Ver Levinson, 2007:42-56. 
interpretação de parte de um destinatário (Vidal, 2002). Isso torna a pragmática um procedimento empírico que estuda como os sujeitos interlocutores usam e interpretam enunciados em determinado contexto de comunicação, o que revela o potencial dela para tornar-se uma teoria crítica e nos anima a perseguir um projeto teórico e metodológico que pode revelar-se promissor para a narratologia.

Transplantar as propostas da pragmática para um projeto de narratologia é certamente uma atitude problemática que suscita inúmeros desafios não tratados aqui. Porém, nada me impede de ousar, reconhecendo a necessidade de refinamentos posteriores. Me dedicarei em seguida a dois aspectos particulares da pragmática que requerem uma atenção imediata devido ao seu peso metodológico em uma narratologia crítica: 1) o protagonismo dos atores; 2) o contexto comunicativo e os dêiticos. Antes, porém, uma advertência sobre o uso do adjetivo 'crítica' na análise que proponho: a meu ver, a possibilidade de incorporar o contexto nos procedimentos de análise consolida uma pragmática expandida como uma teoria crítica. ${ }^{27} \mathrm{O}$ adjetivo crítica tem aqui um valor particular, pois não significa formar juízos de valor, mas sim assumir uma proficiência metodológica a fim de incorporar de maneira rigorosa e fundamentada o papel dos interlocutores e os elementos do contexto comunicativo e cultural nos próprios procedimentos, o que dá à análise da comunicação narrativa um alcance social e histórico. ${ }^{28}$

\footnotetext{
${ }^{27}$ Crítica, observa Paul Ricoeur (1983:21) citando o famoso adágio de F. Scheleiermacher, é o "propósito de lutar contra a não-compreensão: há hermenêutica onde houver não compreensão; romântico, é o intuito de compreender um autor tão bem, e mesmo melhor do que ele mesmo se compreendeu".

${ }^{28}$ Em sua origem, a análise crítica provém do marxismo. Diversos autores fornecem elementos estimulantes que podem, com precauções, serem transportados para um projeto de análise crítica das narrativas. Entre os marxistas, destaco duas obras do crítico literário inglês Terry Eagleton: Marxism and literary criticism (2002) e Criticism E Ideology (2006), ambos originais publicados em 1976. Entre os não-marxistas, destaco o crítico literário canadense Northrop Frye em seu The critical path (1971), e a segunda parte de Interpretação e ideologias, de Paul Ricoeur (1983), onde ele discute sua hermenêutica crítica.
} 


\section{Protagonismo de narradores e destinatários}

A primeira contribuição relevante da pragmática para o projeto de uma narratologia crítica é levar em conta o protagonismo dos sujeitos interlocutores - narrador e destinatário - nos procedimentos de análise. Mais que uma questão de identidade, é necessário que o analista conheça os papéis sociais dos sujeitos, suas intenções comunicativas e as relações de força entre eles (posição social, hierarquia, diferença de gênero, etc.). A pragmática chama o sujeito enunciador de emissor, mas na teoria narrativa é mais adequado denominá-lo narrador, termo que adotarei por conferir a essa figura um ativo protagonismo. Diferente da teoria literária clássica, na pragmática, o narrador é um sujeito real que atua no momento em que emite a sua narração, com seus valores, vontades históricas e uma performance comunicativa concreta. ${ }^{29}$ Da mesma maneira, o destinatário é também um sujeito (ou sujeitos) ativo que se engaja no ato comunicativo por vontade própria, com sua memória, seus valores e ideologias. O destaque, portanto, é a performance dos sujeitos interlocutores. O que move ambos é a vontade coletiva de fazer sentido. Na comunicação narrativa, alguém quer utilizar as técnicas de enunciação dramática para envolver o destinatário, ainda que essa vontade se realize às vezes cooperativamente e outras vezes conflituosamente. Mas o destinatário também participa do ato comunicativo por vontade própria.

O narrador é quem inicia a atividade de contar conforme sua vontade e manipula a linguagem a fim de obter a realização de suas intenções comunicativas. Mas, não é só ele quem toma a iniciativa. Como diz Bakhtin (2003), o ouvinte tem igualmente desejos, se engaja no processo comunicativo com interesses próprios, e tem posturas ativas de resposta: pode não estar de acordo, precisa completar lacunas de sentido,

\footnotetext{
${ }^{29} \mathrm{Na}$ teoria literária narrador e destinatário têm uma especificidade ontológica, um estatuto ficcional, primordialmente textual, diferente do autor, leitor ou audiência concretos. O narrador é o enunciador do discurso, que pode ou não corresponder a um sujeito real (Reis e Lopes, 2007:257-8).
} 
se prepara para uma outra ação, etc. A simples compreensão de um discurso, diz o autor, tem sempre algum grau de resposta, ainda que ela só venha a ocorrer tempos depois. Ambos sujeitos estão imbuídos do desejo de produzir sentidos e, neste sentido, são protagonistas do ato comunicativo. A correlação de forças entre eles pode ser simétrica ou assimétrica, hierárquica ou igualitária, predominando a cooperação ou o conflito. Identificar os lugares que os sujeitos interlocutores ocupam hierarquicamente, seus papéis sociais, suas motivações, a correlação de poder entre eles no ato narrativo é o primeiro passo que um analista precisa dar ao se propor uma interpretação crítica.

Dissemos acima que a comunicação só se completa quando o destinatário reconhece as intenções do falante. Isso ocorre também na comunicação narrativa. Quando alguém escolhe contar, pretende seduzir, envolver, fazer rir ou chorar, impactar o outro de alguma forma. O significado, como diz Searle (2001:127-130) é uma forma de intencionalidade derivada:

\begin{abstract}
A intencionalidade original do pensamento de um falante se transfere às suas palavras e textos, [...] que possuem uma intencionalidade derivada do pensamento do falante. Elas não possuem apenas o significado linguístico convencional, mas também o significado que o falante a elas quis dar. [...] Quando nos comunicamos com alguém, logramos que esse alguém reconheça nossa intenção de produzir compreensão. A comunicação é peculiar entre as ações humanas no sentido que conseguimos produzir o efeito pretendido no ouvinte ao lograr que ele reconheça a intenção de produzir esse mesmo efeito ${ }^{30}$.
\end{abstract}

Toda narração é um ato carregado de intenções: o narrador sempre realiza algo além de proferir uma história literal: ele não só 'convida'

30 Tradução livre do autor. 
alguém a ouvi-lo, mas também busca seduzir esse alguém, modificar seu espírito, envolvê-lo e, principalmente, fazê-lo compreender como o mundo funciona.$^{31}$ As narrativas são um meio de sensibilizar e mobilizar pessoas, obter consenso, criar o senso comum (Bruner, 1998). Neste sentido, a construção de uma intriga (fática ou fictícia) é o ato de organizar a realidade de uma maneira coerente e compreensível a fim de obter a aquiescência e/ou efeitos junto aos interlocutores. Assim, o analista pragmático precisa identificar no texto pistas e traços que indutivamente lhe permitam chegar até as intenções de um narrador diante de um (ou vários) destinatários.

Já dissemos que o envolvimento entre os sujeitos interlocutores pode ocorrer de maneira cooperativa ou conflituosa. Em si, a relação de interlocução é sempre solidária na medida que, no ato comunicativo, um sujeito valida a fala do outro, e vice-versa (independente da concordância sobre o conteúdo). Na comunicação face a face, há turnos de fala, permutas flexíveis e incessantes adaptações. Na comunicação mediada, há pouca ou nenhuma interação, embora a interlocução sempre esteja presente de maneira mais ou menos tangível. O mundo da vida costuma ser desigual, há sempre assimetrias sociais e culturais (antagonismos de classe, gênero, profissão, religião, hierarquia política, institucional ou familiar, etc.) que levam à diferentes pontos de vista sobre os acontecimentos. Há sempre forças antagônicas operando e a relação de confronto é mais usual. O significado resulta de uma disputa (quase sempre velada), mais que de cooperação (no sentido do conteúdo em questão).

Torna-se então útil compreender as narrativas como instrumentos de disputas, estratégias de argumentação, convencimento e cooptação.

\footnotetext{
${ }^{31}$ Searle (2001:81) explica assim o conceito de intencionalidade: "Meus estados subjetivos me relacionam com o resto do mundo e o nome geral dessa relação é intencionalidade. Esses estados subjetivos incluem crenças e desejos, intenções e percepções, assim como amores e ódios, temores e esperanças. Intencionalidade, repitamos, é o termo geral para as diversas formas mediante as quais a mente pode ser dirigida à - ou referir-se à - objetos e estados de coisas no mundo". (Livre tradução do autor).
} 
Nessa perspetiva, as narrativas passam a serem vistas como instrumentos de naturalização do mundo e de legitimação de papéis. Elas podem ser instrumentos de imposição e dominação, embora talvez seja mais usual situações onde elas funcionam como objetos de disputa e barganha pelas representações do mundo. Como ensina Foucault (2010), o poder flutua, vai e volta, inverte e reverte, está sempre em disputa e renegociação. Pessoas, grupos e classes estão sempre em disputa por narrativas hegemônicas. Há convergência, divergência e permuta constante por interpretações mais legítimas. Conforme observa Kerbrat-Orecchioni (2006:74), a interlocução é um processo dinâmico no qual nada é determinado de uma vez por todas, pois o tabuleiro se modifica constantemente:

\begin{abstract}
As trocas comunicativas são o lugar de batalhas permanentes pela alta posição (batalhas mais ou menos discretas ou alardeadas, corteses ou brutais), quer se trate de trocas institucionalmente desiguais, nas quais o jogo dos taxemas pode infletir, e até mesmo inverter (pelo menos provisoriamente) a relação de lugares inicial; ou de trocas, em princípio iguais, nas quais sua ação pode constituir uma relação de dominação a priori inexistente.
\end{abstract}

A disputa por narrativas mais 'verdadeiras' e mais 'naturais' é a força que move os sujeitos narradores e destinatários no mundo da vida. Que razão motiva alguém a organizar a realidade narrativamente? O que pretende alguém ao contar uma história? Que efeitos de sentido pretende produzir no destinatário? Nenhuma narrativa é ingênua, toda narrativa realiza algo, realiza jogos de linguagem e de poder: atrair, conquistar, excitar, motivar, cooptar, mobilizar, etc. Por isso, toda narrativa é argumentativa, pois é dotada de intencionalidade, orienta-se para mudar espíritos, realizar determinado efeito de sentido. Se alguém escolhe organizar narrativamente seu discurso, 
é porque sabe, intuitiva ou racionalmente, que o relato é a melhor estratégia para realizar suas intenções comunicativas. Todo narrador conhece o potencial de sedução e envolvimento que a narrativa detém. Narrativas são dispositivos argumentativos, representam o uso consciente ou inconsciente para criar uma cooperação induzida. $\mathrm{O}$ ato de argumentar e orientar o discurso no sentido de determinadas conclusões constitui o ato linguístico fundamental, pois a todo e qualquer discurso subjaz uma ideologia (Kock, 2002). A argumentação constitui a atividade estruturante de qualquer discurso, e particularmente das narrativas. É através da análise pragmática e retórica que se conhecerá o jogo de poder e as ideologias, dos quais a narrativa é uma parte tangível. Como nenhum ato narrativo se reproduz duas vezes, resta ao analista identificar no texto os traços e pistas que revelem as intenções comunicativas e sua realização (ou não). Isso torna a teoria narrativa uma teoria da argumentação, e sua interpretação, uma análise da retórica argumentativa que desvelará os ardis e artimanhas argumentativos. Os jogos de poder, enfim.

\section{Contexto e dêiticos da situação comunicativa}

A segunda contribuição relevante da abordagem pragmática para o projeto de uma narratologia crítica é a incorporação do contexto aos procedimentos de análise. É a incorporação de determinantes contextuais que dá à análise um caráter crítico e a difere de outras metodologias. Os autores acima citados enfatizam a importância que o contexto e as circunstâncias da situação de comunicação (os fatores extralinguísticos) têm no processo de construção das representações sociais. Cada ato de fala narrativo ocorre em um ambiente psicossocial específico, que sempre contingencia tal ato.

Argumentando que a hermenêutica só se torna relevante devido à múltipla significação dos textos, e que o intérprete precisa ter 
sensibilidade ao contexto, Ricoeur (1983:19) observa: "A sensibilidade ao contexto é o complemento necessário, e a contrapartida inelutável da polissemia". O manejo do contexto, prossegue ele, põe em jogo o discernimento da permuta concreta de mensagens entre interlocutores precisos, atividade propriamente dita da interpretação: "reconhecer qual a mensagem relativamente unívoca o locutor construiu apoiado na base polissêmica". Identificar essa intenção de unicidade na recepção das mensagens é "o primeiro e mais elementar trabalho da interpretação".

Gostaria de me deter sobre os fatores de contingenciamento que atuam de maneira decisiva, em maior ou menor grau, sobre a configuração das histórias. A partir de uma breve revisão da literatura, farei ao final uma sugestão para a incorporação desses fatores aos procedimentos de análise através da consideração dos ciclos dêiticos. O contexto é tão importante para a passagem do significado da sentença ao significado da enunciação que o filósofo Max Black propôs certa vez que a nascente disciplina se chamasse contextics a fim de dar conta de todos os aspectos do contexto relevantes para a linguagem. (Dascal, 2007:561). A questão metodológica da incorporação do contexto na análise da narrativa não é entretanto um problema fácil. É preciso primeiro delimitar o quê é o contexto, seus limites, e qual a sua relevância para cada ato de fala. Isso abre um amplo leque de possíveis fatores pertinentes. O que é ou não é relevante para os participantes em cada ato discursivo? Até onde se expande o entorno que intervém no processo comunicativo? Qual é a força relativa de cada um dos fatores? ${ }^{32}$ Mais complicado ainda é

\footnotetext{
${ }^{32}$ Não se trata aqui de uma questão de variáveis dependentes ou independentes, como certa ciência social positivista professa. A medida exata da interferência de cada fator do contexto sobre a coconstrução compartilhada das representações sociais é uma questão cognitiva que dificilmente poderá ser delimitada com precisão, pois o reconhecimento recíproco dos parceiros do ato interlocutivo se processa através de sucessivas hipóteses-testes: em uma situação concreta o que o locutor faz é avançar uma hipótese para seu interlocutor esperando que ele interprete suas motivações. Não faltam, entretanto, inúmeras situações de mal-entendidos. No entanto, algum tipo de interferência do contexto precisa ser assumida pelo analista no momento da interpretação. Quanto mais seguro e maior domínio ele retiver do contexto, mais convincente será a sua interpretação.
} 
incorporar as relevâncias contextuais nos próprios procedimentos de análise, como veremos.

Para tornar a análise definitivamente crítica, sugiro observar os fatores extralinguísticos como instrumentos de um jogo de poder que se manifesta nos discursos narrativos de maneira argumentativa, conforme observei acima. Penso que uma correlação de forças proveniente do ambiente psicossocial está sempre condicionando cada ato narrativo, mesmo aqueles atos aparentemente despretensiosos, como a mãe que conta uma singela história de fadas ao seu filho pequeno ao anoitecer. Ao contar, a mãe não é totalmente despretensiosa: ela tem a intenção de acalmar e ninar sua cria. Há uma intencionalidade implícita no ato de contar. A narrativa da mãe realiza um ato performativo ao embalar a criança. O relato dela é um texto, mas é também uma atividade social que existe em par com outras formas semelhantes, e com elas se interrelaciona, conforme observa (Eagleton, 2006). Assim, não há ato de fala que não seja argumentativo, nem ato de fala que não carregue alguma carga ideológica. Uma reciprocidade de forças, de encantamento, empatia ou mútua compulsão, próprias de cada ação humana, move e condiciona sempre a configuração de qualquer narrativa. O relato é o resultado dessa recíproca volição. Embora a vontade de sentido não signifique sempre afinidade, como observei acima. Haverá divergência sempre que houver assimetria psicossocial.

Metodologicamente, como delimitar as forças que movem os atores e condicionam cada ato de fala? A resposta a essa pergunta não é fácil. Há na literatura variadas sugestões sobre a extensão do entorno a considerar. A maioria dos autores refere-se à identidade dos sujeitos interlocutores, ao conhecimento compartido por eles, à situação da comunicação (lugar e tempo), e suas circunstâncias sociais. Citando Corseriu (1967), Vidal (2002:30) enumera seis componentes não-linguísticos do contexto que, segundo ela, influem decisivamente: 1) contexto físico (coisas que estão à vista); 2) contexto 
empírico (o estado das coisas objetivas em um momento determinado); 3) contexto natural (totalidade de contextos empíricos possíveis); 4) contexto prático (a conjuntura particular objetiva e subjetiva onde ocorre a fala); 5) contexto histórico (circunstâncias históricas conhecidas pelos interlocutores); 6) contexto cultural (a tradição cultural da comunidade dos interlocutores). Segundo Vidal, só o primeiro seria um fator externo objetivamente descritível, os demais seriam componentes relacionais que geram conceitualizações subjetivas. Esses componentes são sugestivos ao circunscreverem limites. No entanto, parecem vagos, pouco claros, e sobrepostos.

Vidal oferece uma contribuição própria ao discorrer sobre a 'informação pragmática' compartida, segundo ela, o conjunto de conhecimentos, crenças e sentimentos dos interlocutores no momento da interlocução: uma "internalização da realidade objetiva". Citando van Dijk (1989), Vidal diz que a informação pragmática tem um caráter geral (conhecimento de mundo), situacional (percepções recíprocas durante a interlocução) e contextual (aquilo que deriva das expressões linguísticas dos discursos imediatamente precedentes), que na sua teoria da relevância Sperber e Wilson (1986) preferem chamar de "entorno cognitivo compartido" ao se referir às representações mentais compartilhadas. Vidal sugere que o termo 'entorno cognitivo' parece modesto demais para dar conta de toda a informação pragmática que se comparte, porque considera que as relações sociais influem pelo simples fato de ambos interlocutores fazerem parte de uma mesma comunidade social.

Dascal (2006), por sua vez, afirma que todos os textos são opacos e necessitam do contexto para serem interpretados. A função do contexto, diz ele, é fornecer pistas para a geração de hipóteses interpretativas, cuja validade deve ser interpretada à luz da informação referencial. Em princípio, continua ele, qualquer informação contextual pode ser relevante, e neste sentido, é impossível restringir o contexto a determinado conjunto de dados. Ele sugere dois tipos 
gerais de contexto, um metalinguístico (gênero, normas, situação comunicativa, etc.) e outro extralinguístico (universo de referência, conhecimento de fundo, crenças compartilhadas, hábitos e idiossincrasias do falante, etc). E apresenta um ilustrativo gráfico de pistas interpretativas (Dascal, 2006:195-199) que vão das estruturas linguísticas ao conhecimento de mundo compartilhado (cultura, ideologia). $\mathrm{O}$ autor sugere que o analista proceda a partir de pistas (clues) e dicas (cues). A interpretação das dicas seria um processo dedutivo, enquanto o das pistas seria indutivo.

\section{Deixais ampliada: a atualização do contexto nos significados}

Levinson (2007:65) apresenta uma alternativa instigante sobre a relação entre a língua e o contexto. Para ele, essa relação revela a importância da dêixis. É através da dêixis que "as línguas gramatilizam traços do contexto da enunciação", diz ele. O Dicionário de Linguística de Jean Dubois (1973:168) define a dêixis de maneira semelhante ao Dicionário de Retórica de A. Marchese e J. Forradellas (1998:92). Dêixis, segundo ambos dicionários, seriam as coordenadas espaço-temporais da enunciação: o sujeito refere o seu enunciado ao momento da enunciação, aos participantes da comunicação e ao lugar em que o enunciado se produz. As referências a essa situação formariam a dêixis, um modo particular de atualização que utilizaria o gesto (dêixis gestual) ou termos da língua chamados dêiticos verbais. Apresentando uma classificação restrita da dêixis, ambos dicionários citam U. Weinreich, que propõe quatro influentes fatores da situação, organizados a partir da pessoa que fala: 1) a origem do discurso (o eu) e o interlocutor (o tu); 2) o tempo do discurso (o agora); 3) o lugar (aqui, aí); 4) identidades substitutas na situação.

Para Levinson (2007:74), autor do qual tomaremos emprestado ideias para elaborar a proposta aqui desenvolvida, a dêixis diz respeito 
às maneiras pelas quais a linguagem gramaticaliza traços do contexto no ato de fala. Decorre daí que a interpretação precisa levar em conta o contexto dêitico da enunciação, pois só as sentenças consideradas em contextos específicos expressam proposições definidas: "é apenas o contexto de uso que nos diz de que maneira compreender (as sentenças)". Em geral, a dêixis é organizada de maneira cêntrica a partir do falante, ancorada em pontos específicos do acontecimento comunicativo, criando os centros dêiticos: a pessoa central é quase sempre o falante, o tempo central é o tempo em que o falante produz a enunciação, o lugar central é a localização do falante, assim como o centro social é a posição social e hierárquica do falante, à qual a posição dos destinatários é relativa. Irradiando-se do falante, completa Levinson, há vários círculos concêntricos que distinguem diferentes zonas de proximidades espacial e temporal. A partir dele, linearmente ordenada, parte a linha que estabelece os acontecimentos do passado e do futuro, etc. Apesar do autor realçar a pessoa do falante como referência de partida, a meu ver os círculos dêiticos devem ser considerados em termos do relacionamento dele com o seu interlocutor, conforme aqui farei.

A ideia de círculos dêiticos concêntricos parece-me capaz de representar de maneira sistemática as influências do contexto sobre os atos de fala. Essas influências estão sintetizadas na Figura 1. Partindo da localização espaço-temporal do falante e seu interlocutor, de onde irradiam os dêiticos, e das informações pragmáticas, os círculos concêntricos se expandiriam desde as condicionantes situacionais mais empíricas (o aqui e agora do ato) até as mais sutis, de caráter mais subjetivo (culturais, políticas, ideológicas), situadas nos ciclos mais externos. 


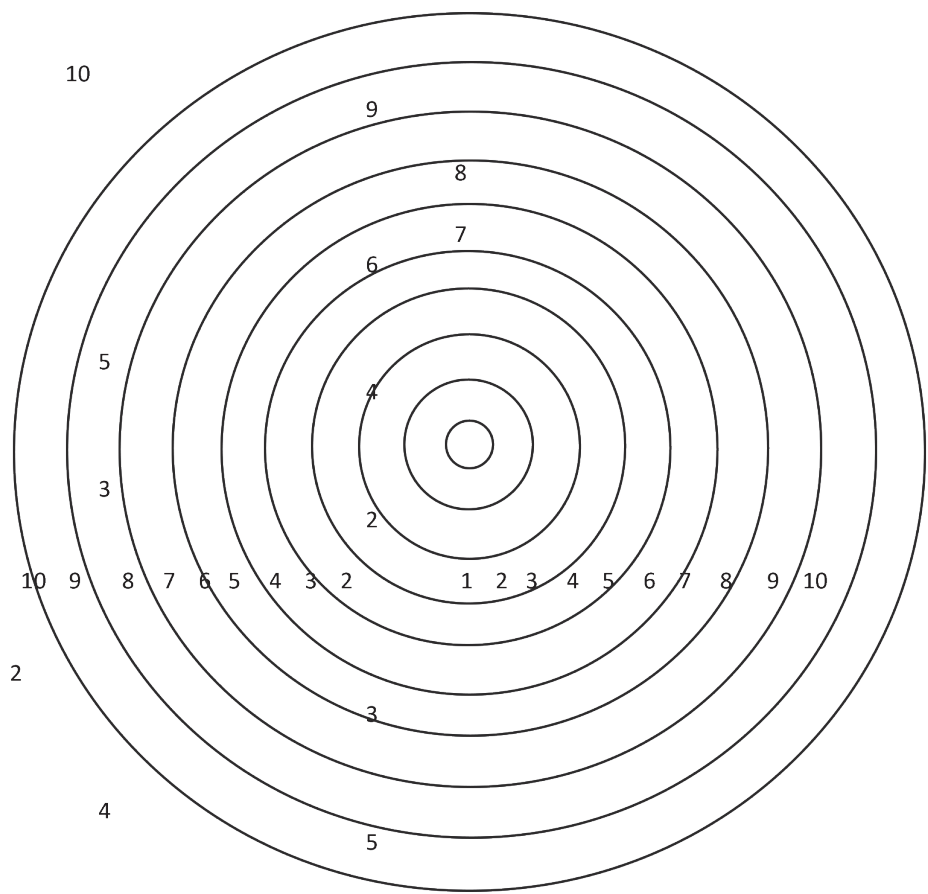

6

7

8

9

Figura 1. Dêiticos Concêntricos dos Atos de Fala

1) Identidade dos sujeitos participantes, o lugar social que ocupam, seus interesses e intenções comunicativas; 2) Coações institucionais, normas profissionais, etc.; 3) graus de hierarquias entre os sujeitos da enunciação e suas condicionantes na interlocução; 5) Espaço físico e sua influência na enunciação; 6) Percepções recíprocas por parte dos participantes dos fatores anteriores; 7) Circunstâncias históricas de ocorrência do ato; 8) Circunstâncias culturais, crenças, mitologias, ideologias, conhecimento de mundo compartido; 9) Memória coletiva de curto e longo prazos; 10) Percepções recíprocas de todo este conjunto de fatores. 
Não será possível aqui explorar com minúcias as sugestões e problemas que surgem da proposta apresentada na Figura 1. Ressalto, porém, que a figura não pretende enquadrar relações de natureza intersubjetiva. A tentativa de colocá-las em uma figura gráfica é apenas ilustrativa. Penso, no entanto, que a imagem de círculos dêiticos pode fornecer pistas sugestivas para as hipóteses interpretativas, tornando a interpretação menos míope. Os fatores indicados nos círculos da figura não possuem fronteiras precisas nem devem ser tomados como 'variáveis antecedentes' objetivas, como já se disse. Eles se superpõem, se influenciam mutuamente e funcionam como uma cadeia de indicadores psicossociais intersubjetivos. Não obstante, ao visualizar os níveis dêiticos, o analista poderá estabelecer hipóteses consistentes, a partir das quais produzir uma interpretação mais sistemática e orientada. Os níveis dêiticos são apenas indicadores a partir dos quais as pistas e traços argumentativos da linguagem narrativa poderão ser interpretados de maneira mais segura. Mas atenção, os fatores que estão no centro ou periferia do modelo apresentado não possuem per se maior ou menor força indutora que os demais. A força determinante de cada nível do contexto dependerá da situação concreta do ato comunicativo, assim como da pergunta de pesquisa de cada projeto.

Parafraseando mais uma vez P. Ricoeur, o que deve ser interpretado em um texto narrativo é a sua proposição de mundo. Não há - observa ele - uma intenção oculta a ser procurada detrás do texto, mas um mundo a ser manifestado diante dele. Por isso, a interpretação precisa ser altiva e ideologicamente crítica, pois o gesto interpretativo é uma 'oposição' às distorções da comunicação humana. Por outro lado, o discurso é um evento que remete aos seu interlocutores, vincula-se às pessoas que falam e ouvem, e a algo ao qual ele se refere (um mundo que pretende descrever, exprimir ou representar). Neste sentido, completa Ricoeur (1983:46), "o evento é a vinda à linguagem de um mundo mediante o discurso". O que 
importa, pois, é a seletividade dos contextos na determinação do valor das palavras e frases a respeito de um determinado evento, pronunciadas por um locutor preciso frente a um ouvinte em uma situação particular.

Retomo, para concluir, às perguntas que originaram as reflexões deste ensaio: como incorporar as determinantes ambientais e históricas na análise da narrativa tornando-a uma análise crítica por natureza? Respondo de maneira objetiva: observando previamente quais motivações e propósitos movem os sujeitos interlocutores a se envolverem em um ato de interlocução. Perguntando previamente: que ímpeto move um narrador a configurar certa proposição de mundo na forma de uma história, em determinada circunstância? Por outro lado, porque determinado indivíduo ou segmento social se presta ao papel de audiência? Que interesses têm cada um dos participantes do ato comunicativo ao se engajar no esforço de coconstruir uma representação narrativa do mundo? Qual é o protagonismo discursivo de cada um deles neste ato? Que circunstâncias cercam esse protagonismo? Há antagonismos? Qual é a correlação de poder entre os protagonistas?

Como observei no início deste ensaio, a textura geral da experiência é hoje transmidiática: entramos e saímos seguidamente no espaço das mídias, de onde retiramos extratos de significação com os quais configuramos as nossas representações de mundo. Nesse complexo contexto, a performance dos agentes interlocutores tornou-se mais proeminente ainda, e a incorporação desse protagonismo à análise, ainda mais relevante. Neste rumo, trouxemos aqui a sugestão de uma teoria ampliada de círculos dêiticos que, a meu ver, fornece subsídios relevantes para a análise das narrativas como atos de fala dinâmicos e circunstancializados. Se a análise imanentista já se revelara obsoleta pelo desprezo ao protagonismo dos agentes, ela revela-se hoje ainda mais inapropriada frente ao dinamismo das narrativas em permanente processo de configuração e refiguração no interior da cultura da convergência. 
Seguindo este raciocínio, propus neste ensaio encarar a narração como um ato de fala comunicativo, e utilizar o modelo dos círculos dêiticos concêntricos para tornar mais sistemático o processo de identificação dos traços e vestígios do contexto no texto, modelo capaz de revelar o jogo de forças de uma ação interlocutiva concreta. Nada garante uma interpretação segura, mas creio que a sugestão de se trabalhar com os ciclos concêntricos dêiticos oferece a alternativa de o analista partir de um lugar mais confortável e confiável para fazer as suas induções. As estratégias argumentativas, os subentendidos e os efeitos de sentido tornarão mais evidentes a proposição de mundo que o texto traz, e proporcionarão uma análise mais forte: a interpretação narrativa torna-se ipso facto uma crítica da sociedade.

\section{REFERÊNCIAS BIBLIOGRÁFICAS}

AUSTIN, J. H. (1962). How to do Things with Words: The William James Lectures delivered at Harvard University, Oxford: Clarendon Press.

BAKHTIN, M. (2003). Estética da criação verbal. S. Paulo: Martins Fontes.

BERLIN, I. (1997). The proper study of mankind. London: John Murray.

CORSERIU, E. (1967). "Determinación y entorno". in Teoria del lenguaje y linguística general. Gredos: Madrid.

DASCAL, M. (2006). Interpretação e compreensão. S. Leopoldo: Ed. Unisinos.

DIJK, T. A. van (2000). Cognição, discurso e interação. S. Paulo: Contexto.

DIJK, T. A. van (1987). In La pragmática de la comunicación literária, J. A. Mayoral, Arco, Madrid.

DUBOIS, J. et al. (2004). Dicionário de linguística. S. Paulo: Cultrix.

EAGLETON, T. (2002). Marxism and literary criticism. London: Routledge.

EAGLETON, T. (2006). Criticism \& Ideology. London: Verso.

FIORIN, J. L. (2005). As astúcias da enunciação. S. Paulo: Ática.

FRYE, N. (1971). The critical path. Indiana University Press, Bloomington: Midland Books. 
GRICE, H. P. (1957). "Meaning". in The Philosophical Review. Vol. 66, No. 3. (Jul., 1957), pp. 377-388.

GRICE, H P. (1969). "Utterer's meaning and intentions". in Philosophical Review. Vol. 78, pp. $147-177$.

LEVINSON, S. C. (2007). Pragmática. S. Paulo: Martins Fontes.

JENKINS, H. (2012). Cultura da convergência. S. Paulo: Aleph.

KOCK, I. V. (2011). Argumentação e linguagem. S. Paulo: Cortez.

MARCHESE, A. e J. Forradellas (1998). Diccionário de retórica, crítica y terminologia literária. Barcelona: Ariel.

MOTTA, L. G. (2013). Análise crítica da narrativa. Brasília: Ed. UnB.

MOTTA, L. G. (2006). Notícias do fantástico. S. Leopoldo: Ed. Unisinos.

REYES, G. (1994). La pragmática lingüística. Barcelona: Montesinos.

RICOEUR, P. (2010). Tempo e narrativa 3. S. Paulo: Martins Fontes.

RICOEUR, P. (1995). Tempo e narrativa 2. Campinas: Papirus.

RICOEUR, P. (1994). Tempo e narrativa 1. Campinas: Papirus.

RICOEUR, P. (1983). Interpretação e ideologias, Francisco Alves, Rio de Janeiro.

SCOLARI, C. A. (2009). "Transmedia storytelling: implicit consumers, narrative worlds and branding contemporary media productions". in International Journal of Communication 3, pp. 586-606.

SEARLE, J. R. (2001). Mente, lenguaje y sociedad. Alianza, Madrid.

SEARLE, J. R. (2002). Intencionalidade. S. Paulo: Martins Fontes.

SEARLE, J. R. (2002a). Expressão e significado. S. Paulo: Martins Fontes.

SILVERSTONE, R. (1999). Why study the media? London: Sage.

SPERBER, D. e WILSON, D. (1986). La relevância. Madrid: Visor.

VIDAL, M. V. E. (2002). Introducción a la pragmática. Barcelona: Ariel.

Villanueva, L. M. V. (2000). La búsqueda del significado. Madrid: Tecnos. 